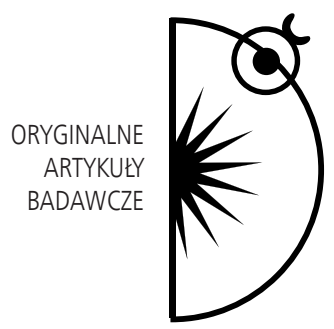

Małgorzata Jonczy-Adamska

\title{
Edukacja antydyskryminacyjna a ukryty program nauczania. Słowo i obraz
}

DOI: http://dx.doi.org/10.12775/PBE.2013.012

\section{Wprowadzenie}

Edukacja antydyskryminacyjna to świadome działanie podnoszące poziom wiedzy, umiejętności i wpływające na postawy, mające na celu przeciwdziałanie dyskryminacji i przemocy motywowanej uprzedzeniami oraz wspieranie równości i różnorodności. Edukacja antydyskryminacyjna rozwija wiedzę na temat mechanizmów dyskryminacji i wykluczenia, buduje kompetencje przeciwdziałania dyskryminacji. Rozwija także wiedzę na temat grup dyskryminowanych i ruchów emancypacyjnych oraz wzmacnia te grupy i osoby do nich należące na zasadzie włączenia i upodmiotowienia ${ }^{1}$.

Gdzie jest miejsce edukacji antydyskryminacyjnej w edukacji formalnej? Czy w polskiej szkole jest przestrzeń dla treści promujących świat wolny od dyskryminacji i przemocy motywowanej uprzedzeniami? Czego dowiadują się polskie uczennice i uczniowie na temat grup wykluczanych, dyskryminowanych, do których część z nich także należy? W jaki sposób przygotowują się do uwzględniania takich tematów w swojej pracy nauczycielki i nauczyciele? $\mathrm{Na}$ te $\mathrm{i}$ inne pytania szukano odpowiedzi w projekcie badawczym Wielka nieobec-

${ }^{1}$ Definicja edukacji antydyskryminacyjnej wypracowana przez Towarzystwo Edukacji Antydyskryminacyjnej, www.tea.org.pl (dostęp: 9.10.2013) 
$n a-o$ edukacji antydyskryminacyjnej w systemie edukacji formalnej $w$ Polsce zrealizowanym przez Towarzystwo Edukacji Antydyskryminacyjnej². Badanie stanowiło próbę odpowiedzi na dwa kluczowe pytania:

1. W jaki sposób formalny system kształcenia i doskonalenia nauczycielek/ /nauczycieli rozwija ich kompetencje w obszarze przeciwdziałania dyskryminacji i umożliwia zdobywanie wiedzy związanej z równością i różnorodnością?

2. W jakim stopniu w polskiej szkole obecne są kwestie równości, różnorodności, praw człowieka oraz zjawisk dotyczących uprzedzeń, dyskryminacji, wykluczenia czy przemocy - czy polscy uczniowie i uczennice mogą rozwijać w szkole kompetencje związane z edukacją antydyskryminacyjną?

W związku ze złożonością rzeczywistości szkolnej tematyki antydyskryminacyjnej szukano w bardzo różnych obszarach. Analizie poddano następujące dokumenty oraz publikacje związane z życiem szkoły:

- podstawy programowe kształcenia ogólnego dla szkół podstawowych, gimnazjów i szkół ponadgimnazjalnych,

- 55 podręczników i zeszytów ćwiczeń do historii, języka polskiego, wiedzy o społeczeństwie i wychowania do życia w rodzinie,

- standardy kształcenia i doskonalenia nauczycielek oraz nauczycieli w Polsce,

- ofertę 18 ośrodków doskonalenia nauczycielek/nauczycieli,

- ofertę Ośrodka Rozwoju Edukacji,

- ofertę studiów podyplomowych dla nauczycielek/nauczycieli.

Uzupełnieniem były bezpośrednie spotkania z nauczycielkami i nauczycielami analizowanych przedmiotów (wywiady fokusowe, w których udział wzięło 21 osób) oraz wywiady pogłębione z ekspertkami i ekspertami ds. systemu edukacji (sześć osób).

Wyniki badań zrealizowanych w projekcie nie pozostawiają żadnych wątpliwości - edukacja antydyskryminacyjna jest realizowana w polskiej szkole w bardzo niewielkim stopniu, często przypadkowo, w zależności od postaw, dobrej woli nauczycielek/nauczycieli czy autorek/autorów podręczników. Nauczycielki i nauczyciele wyrażają przekonanie, że taka edukacja nie jest potrzebna lub że integracyjny charakter szkoły wystarczy, żeby promować posta-

\footnotetext{
${ }^{2}$ Projekt Towarzystwa Edukacji Antydyskryminacyjnej pn. Wielka nieobecna - o edukacji antydyskryminacyjnej w systemie edukacji formalnej w Polsce był realizowany ze środków Fundacji im. Stefana Batorego w ramach programu „Demokracja w działaniu” w latach 2010-2011.
} 
wy wolne od uprzedzeń. Osoby z grona pedagogicznego chętnie powołują się na zapisy dotyczące tolerancji, poszanowania godności, szacunku, które jednak funkcjonują w szkole na takim poziomie ogólności, że rzadko przekładają się na konkretne działania ${ }^{3}$.

Podstawy programowe i podręczniki zdają się zauważać różne mniejszości w niewielkim stopniu - głównie w kontekście mniejszości narodowych i etnicznych, opisywanych przede wszystkim z powodu wymogu zawartego w podstawie programowej przedmiotu wiedza o społeczeństwie. Trudno jednak oprzeć się wrażeniu, że inne mniejszości - np. seksualne, wyznaniowe, „rasowe", osoby z niepełnosprawnościami, pozostają niewidzialne. We wprowadzeniu do Podstawy programowej kształcenia ogólnego dla szkót podstawowych czytamy:

W rozwoju społecznym bardzo ważne jest kształtowanie postawy obywatelskiej, postawy poszanowania tradycji i kultury własnego narodu, a także postawy poszanowania dla innych kultur i tradycji. Szkoła podejmuje odpowiednie kroki w celu zapobiegania wszelkiej dyskryminacji ${ }^{4}$.

Taki zapis, powtórzony również $\mathrm{w}$ podstawach programowych dotyczących kolejnych etapów kształcenia, przyciąga uwagę i prowokuje do pytań. W jaki sposób rozumiana jest dyskryminacja (nigdzie niezdefiniowana)? W jaki sposób szkoła zapobiega dyskryminacji? Jak konkretnie wyglądają „odpowiednie kroki”"? Czy - przez zestawienie z „poszanowaniem innych kultur i tradycji” mają się one odnosić się wyłącznie do nich? Niestety, w kontekście kolejnych zapisów znajdujących się w podstawie programowej, a także biorąc pod uwagę wyniki badania przedstawionego w tym raporcie, można stwierdzić, że jest to zapis czysto deklaratywny i nie przekłada się na konkretne rozwiązania systemowe funkcjonujące w szkołach (np. podstawy programowe przedmiotów czy treści nauczania). Mówi się tu o „wszelkiej dyskryminacji”, a jednocześnie sankcjonuje nierówne traktowanie ze względu na wyznanie (np. niedostępność/ /ograniczona dostępność lekcji etyki dla dzieci nieuczęszczających na religię w wielu polskich szkołach) czy orientację seksualną (brak jakichkolwiek zapi-

\footnotetext{
${ }^{3}$ Pełna wersja raportu Wielka nieobecna - o edukacji antydyskryminacyjnej w systemie edukacji formalnej w Polsce (red. M. Abramowicz, Towarzystwo Edukacji Antydyskryminacyjnej, Warszawa 2011) dostępna pod adresem www.tea.org.pl w dziale Publikacje.

${ }^{4}$ Podstawa programowa kształcenia ogólnego dla szkót podstawowych, s. 2, http://www.bip. men.gov.pl/men_bip/akty_prawne/rozporzadzenie_20081223_zal_2.pdf (dostęp: 9.10.2013).
} 
sów w podstawie programowej dotyczących osób homoseksualnych, powtarzające się w szkołach zachowania i komentarze o charakterze homofobicznym, naruszające godność uczniów i uczennic o nieheteroseksualnej orientacji lub tych, którym taka orientacja jest przypisywana ${ }^{5}$ ).

W części Zalecane warunki i sposób realizacji, dotyczącej przedmiotu historia i społeczeństwo, czytamy natomiast, że:

Zadaniem szkoły jest kształtowanie u uczniów następujących postaw:

1) zaangażowania $w$ działania obywatelskie: uczeń angażuje się w działania społeczne;

2) wrażliwości społecznej: uczeń dostrzega przejawy niesprawiedliwości i reaguje na nie;

3) odpowiedzialności: uczeń podejmuje odpowiedzialne działania w swojej społeczności, konstruktywnie zachowuje się w sytuacjach konfliktowych;

4) poczucia więzi: uczeń odczuwa więź ze wspólnotą lokalną, narodową, europejską i globalną;

5) tolerancji: uczeń szanuje prawo innych do odmiennego zdania, sposobu zachowania, obyczajów i przekonań, jeżeli nie stanowią one zagrożenia dla innych ludzi; przeciwstawia się przejawom dyskryminacji ${ }^{6}$.

Ponownie mamy do czynienia z ważnym założeniem, trudno natomiast wyobrazić sobie, na bazie jakiej wiedzy oraz umiejętności uczennice i uczniowie mieliby przeciwstawiać się przejawom dyskryminacji - w takie kompetencje szkoła nie wyposaża.

\section{Ukryty program nauczania}

Z perspektywy edukacji antydyskryminacyjnej bardzo istotne staje się zjawisko ukrytego programu nauczania (ukrytego programu szkoły). Ukryty program nauczania to wszystko to, co zostaje przyswojone podczas nauki w szkole obok oficjalnego programu ${ }^{7}$. Są to zatem treści niezapisane w programie, przekazywane często w nieuświadomiony sposób, zarówno bezpośrednio przez nauczycielki

\footnotetext{
${ }^{5}$ Por. raport Lekcja Równości. Postawy i potrzeby kadry nauczycielskiej i młodzieży wobec homofobii w szkole (red. J. Świerszcz, Warszawa 2012).

${ }^{6}$ Podstawa programowa kształcenia ogólnego dla szkót podstawowych, s. 57.

${ }^{7}$ R. Meighan, Socjologia edukacji, Wydawnictwo Uniwersytetu Mikołaja Kopernika, Toruń 1993, s. 71.
} 
i nauczycieli, jak i w organizacji życia szkoły czy przestrzeni w szkole. Najczęściej są to treści o charakterze wychowawczym, często niosą ze sobą przekazy dotyczące obszarów interesujących w kontekście edukacji antydyskryminacyjnej: stereotypy, uprzedzenia, przemoc, nierówności społeczne z jednej strony, a szacunek dla różnorodności, równość - z drugiej. Ważne także, że działania składające się na ukryty program nauczania nie są celowe, zaplanowane, świadome, nie zakłada się ich przekazu, np. obecność krzyża w salach szkolnych nie zakłada dyskryminacji ze względu na wyznanie, a jednocześnie staje się ukrytym przekazem dotyczącym wagi religii katolickiej przy braku symboli innych religii.

Meighan, odnosząc się do pracy Postmana i Weingartnera z 1971 r., wskazuje, jakie treści mogą być efektem funkcjonowania ukrytego programu nauczania:

- bierna akceptacja jest bardziej pożądana niż aktywny krytycyzm;

- odkrywanie wiedzy jest poza zdolnościami uczniów i w żadnym razie nie powinno ich obchodzić;

- odtwarzanie jest najwyższą formą osiągnięcia intelektualnego, a gromadzenie w pamięci niepowiązanych ze sobą faktów jest celem edukacji;

- własne pomysły i pomysły innych uczniów są bez znaczenia;

- uczucia są nieistotne w uczeniu się;

- zawsze istnieje jedna właściwa odpowiedź na pytanie;

- konkurencja jest ważniejsza od współpracy;

- pisanie i czytanie są ważniejsze niż rozmawianie i myślenie;

- mężczyźni są ważniejsi niż kobiety ${ }^{8}$.

W powyższym fragmencie Meighan odnosi się do jednej z przesłanek dyskryminacji - płci - i zwraca uwagę na to, w jaki sposób różnicowane są przekazy dotyczące kobiet/dziewcząt i mężczyzn/chłopców zawarte w ukrytym programie nauczania. Można tę listę rozszerzyć o podobne podsumowanie w kontekście różnych przesłanek dyskryminacji, bazując na omawianych badaniach. Przykładowe wnioski mogą brzmieć:

- jedyną możliwą formą samorealizacji w życiu prywatnym jest małżeństwo;

- wszyscy ludzie są biali;

- w naszym społeczeństwie nie ma osób starszych;

${ }^{8}$ Tamże, s. 72. Meighan w tej samej publikacji analizuje także wyniki badań odnoszące się do ukrytego programu nauczania w ramach różnych przedmiotów nauczanych w szkole, organizacji lekcji, przestrzeni budynku, zachowań nauczycielek i nauczycieli, czy wreszcie - języka. 
- chłopcy lubią się bić;

- osoby czarnoskóre żyją w Afryce i są ubogie;

- kobiety zajmują się domem i dziećmi, mężczyźni zarabiają pieniądze;

- osoby z niepełnosprawnością są słabe i potrzebują pomocy;

- osoby homoseksualne nie istnieją;

- wyznawcy islamu są terrorystami.

Jak widać, zdecydowanie nie są to przekazy, które promują szacunek dla wszystkich bez względu na przynależność do grup mniejszościowych.

W związku z tym, że treści dotyczące różnych przesłanek dyskryminacji, sytuacji grup mniejszościowych, relacji mniejszość - większość rzadko są ujmowane w podstawie programowej, a w konsekwencji rzadko pojawiają się jako części zaplanowanego procesu uczenia, przekazom tym należy przyglądać się właśnie z perspektywy ukrytego programu.

\section{Więcej niż słowo}

W procesie planowania pracy dydaktycznej często nie przywiązuje się wystarczająco dużej wagi do języka, a zatem narzędzia, jakim posługujemy się, żeby przekazać wiedzę. Nauczycielki i nauczyciele używają go, żeby komunikować się z uczennicami i uczniami, uczą nowych pojęć, języków obcych, uczą deklinacji czy koniugacji. Rzadko natomiast zwraca się uwagę na to, jakie przekazy zawiera sam język. Czy, jeśli powiemy do dziecka „nie cygań!”, jest to jedynie zwrot dotyczący kłamstwa, czy także „środek transportu” dla romofobii. „Podejmij męską decyzję”, „on jest zniewieściały”, „zrobimy sobie wigilię klasową" - tego typu komunikaty padają w polskich szkołach regularnie. W badaniu Wielka nieobecna przyglądano się językowi używanemu przez autorki i autorów podręczników, który z jednej strony częściowo odzwierciedla relacje panujące $\mathrm{w}$ społeczeństwie, $\mathrm{z}$ drugiej - stanowi element utrzymywania tych relacji, przekazywania ich „słusznego” obrazu kolejnym pokoleniom. Dzieje się tak, po pierwsze, w stosunku do płci opisywanych osób, po drugie - w stosunku do grup mniejszościowych, wyróżnianych w polskiej rzeczywistości ze względu na niepełnosprawność, pochodzenie etniczne i narodowe czy wyznanie. Stosowanie języka równościowego jest jednym z postulatów edukacji antydyskryminacyjnej. Wynika to z założenia, że zmiany w języku w obliczu zmieniającej się rzeczywistości są konieczne, niezbędne. Język jest wytworem ludzkim i odzwierciedla rzeczywistość, to my, ludzie, decydujemy, czy jakieś słowo uznajemy za prawidłowe. Jednocześnie, działając na rzecz różnych grup mniejszościowych, w tym na rzecz równości praw kobiet i mężczyzn, eliminu- 
jąc stereotypy i uprzedzenia, warto zwracać uwagę również na te zakorzenione w języku. Język równościowy, zwany też włączającym, jest propozycją zmiany dotychczasowego systemu języka używanego przez większość. Jego celem jest podkreślenie obecności i włączenie perspektyw osób z grupy dotychczas marginalizowanych, a także tworzenie bardziej sprawiedliwych i włączających norm językowych, które odzwierciedlają różnorodność świata9.

Warto tu zwrócić uwagę na gramatykę języka polskiego, która jest skonstruowana w taki sposób, że rodzaj męski (i męskoosobowy) traktowany jest jako uniwersalny. Natomiast ciągle pozostaje rodzajem męskim, formy męski w znaczeniu ogólnym, choć stanowią gramatycznie poprawną formę odnoszącą się do obu płci, psychologicznie pozostają androcentryczne i nie są ani uniwersalne, ani neutralne ${ }^{10}$. Refleksja nad językiem polskim, nad regułami gramatycznymi czy przyzwyczajeniami językowymi, pozwala zobaczyć, na jak wielu polach język preferuje rodzaj męski - określenia rodzaju męskiego odnoszące się do mężczyzn, do kobiet oraz do mieszanych grup ludzi, niezależnie od tego, czy istnieje forma żeńska wyrazu. Te mechanizmy widać w różnych aspektach języka polskiego ${ }^{11}$ :

- użycie rzeczowników męskoosobowych jako nazw gatunkowych (zarówno w liczbie pojedynczej: np. klient, pacjent, nauczyciel, uczeń, jak i mnogiej: obywatele, przedstawiciele, podatnicy, nauczyciele, uczniowie),

- użycie męskich form przymiotników oraz imiesłowów w funkcji rzeczowników gatunkowych (np. zdający, przyjmujący formularz, ubezpieczony, poszkodowani, aresztowani),

- użycie męskich form czasowników (np. zrobił, stwierdził), zaimków (np. nikt, ktoś, nim, który), przymiotników (np. stary, prawdziwy, zmęczony),

- użycie męskoosobowych form czasowników (np. byli, widzieli, przebywali), zaimków (oni, ich, nimi, którzy) oraz przymiotników (mili, skuteczni, stanowczy),

- stosowanie form męskich w poleceniach, instrukcjach, opisach bez względu na adresata/adresatkę (np. co zrobiłbyś, gdyby..., jak pewnie zauważyłeś..., kiedy byłeś dzieckiem...),

${ }^{9}$ D. Cieślikowska, Postrzeganie spoteczne, w: M. Branka, D. Cieślikowska (red.), Edukacja antydyskryminacyjna. Podręcznik trenerski, Willa Decjusza, Kraków 2010, s. 102.

10 Tamże, s. 97.

${ }^{11}$ M. Karwatowska, J. Szpyra-Kozłowska, Lingwistyka ptci. Ona i on w języku polskim, Wydawnictwo Uniwersytetu Marii Curie-Skłodowskiej, Lublin 2005, cyt. za: Cieślikowska D., Postrzeganie spoleczne, s. 95 . 
- umieszczanie form męskich przed żeńskimi (np. jaki, jaka, jakie; który, która, które; trener/ka; uczestnik i uczestniczka).

Najczęściej pytania dotyczące języka wrażliwego na płeć dotyczą nazw zawodów i stanowisk. Większość z nich jest rodzaju męskiego, ponieważ to mężczyźni wcześniej funkcjonowali w życiu publicznym i w związku z ich obecnością $\mathrm{w}$ różnych sferach $\mathrm{w}$ odniesieniu do mężczyzn właśnie kształtowało się nazewnictwo opisujące rzeczywistość, a jednocześnie mieli oni możliwość wpływu na decyzje dotyczące nazw stanowisk czy zawodów. Dodatkową trudność stanowi fakt, że formy żeńskie od wielu nazw zawodów tworzy się podobnie jak zdrobnienia w języku polskim, co u wielu osób budzi obawę, że będzie to brzmiało niepoważnie, śmiesznie: np. piłeczka - książeczka - psycholożka. Przyzwyczajenie się do nowych słów wymaga osłuchania, używania, stałego spotykania się z nimi. Na przykład słowo „studentka” - w tej chwili nie budzi kontrowersji, chociaż wiele kobiet formalnie w spisach uczelni wciąż funkcjonuje jako „studenci”. Natomiast na przełomie wieku XIX i XX, kiedy kobiety rozpoczynały studia na kolejnych kierunkach, słowo „studentka” było używane jako obraźliwe - ,jesteś studentką, nie studentem”. Wcześniej nie było potrzebne, stworzono je dopiero wówczas, kiedy odpowiadało na zmianę w rzeczywistości, na potrzebę konkretnej grupy, która w ten sposób stała się obecna w przestrzeniach uczelni. Bardziej współczesny przykład pochodzi od naszych zachodnich sąsiadów - kiedy Angela Merkel została pierwszą w historii kobietą na stanowisku kanclerza Niemiec, okazało się, że brakuje żeńskiej formy rzeczownika „kanclerz” - po roku została ona przyjęta jako prawidłowe słowo i wpisana do słownika języka niemieckiego ${ }^{12}$. Jednocześnie rodzaj męski i żeński odzwierciedla istniejące podziały w społeczeństwie, segregację poziomą i pionową na rynku pracy, czyli podział rynku pracy na sektory zdominowane przez kobiety i mężczyzn oraz większą obecność mężczyzn na stanowiskach kierowniczych. Wciąż mamy do czynienia z uproszczeniami, do których jesteśmy (również językowo) przyzwyczajeni i przyzwyczajone - mówimy: dziennikarze, politycy, dyrektorzy, towarzyszą im ekspedientki, woźne, sekretarki, pielęgniarki. I w tej drugiej grupie nie mamy żadnych oporów z używaniem form żeńskich. To ważny element socjalizacji, ale też ukryty przekaz, który

${ }^{12} \mathrm{~W}$ języku niemieckim większość nazw zawodów i stanowisk posiada nazwy w rodzaju męski i żeńskim, te drugie tworzone są przez dodanie przyrostka '-in'. W gramatyce języka niemieckiego istnieje też rozwiązanie w przypadku rzeczowników w liczbie mnogiej (wielka litera w środku wyrazu), pozwalające podkreślić, że w definiowanej grupie znajdują się osoby obu płci. W języku polskim obecność jednego mężczyzny obliguje do przyjęcia formy męskoosobowej rzeczownika i czasownika. 
wszyscy dostajemy. Często pojawiają się głosy, że rodzaj męski jest neutralny, ale wystarczy proste ćwiczenie, pokazujące, że tak nie jest - proszę wyobrazić sobie dyrektora dużej firmy. Przed oczami większości z nas stanie mężczyzna w garniturze.

Szczególną uwagę w badaniu obecności edukacji antydyskryminacyjnej w rzeczywistości szkolnej poświęcono obecności języka wrażliwego na płeć w podręcznikach szkolnych. Zdecydowanie najwięcej takich rozwiązań znalazło się w podręcznikach do przedmiotu wiedza o społeczeństwie, natomiast działo się to w różnym stopniu: wyraźnie widać różnice pomiędzy poszczególnymi podręcznikami świadczące o różnej gotowości autorek i autorów do stosowania żeńskich końcówek czasowników czy rzeczowników. Włączenie równości do języka może zatem ograniczać się do sformułowania na początku każdego rozdziału:

Po przeczytaniu tego tekstu i wykonaniu ćwiczeń powinnaś/powinieneś $[\ldots]^{13}$

W innym podręczniku dosyć często stosuje się podwójne formy czasowników, przy czym są to jedynie wybrane fragmenty, stanowiące mniejszość w stosunku do całej treści podręcznika.

Czy wypowiadanie własnego zdania jest zawsze łatwe?

Przypomnij sobie sytuację, w której - choć czułeś/czułaś, że masz coś do powiedzenia i że masz rację - nie zabrałeś/zabrałaś głosu lub zrobiłeś/zrobiłaś to mało stanowczo ${ }^{14}$.

Być liderem

Przypomnij sobie sytuację, w której przewodziłeś/przewodziłaś grupie swoich kolegów czy koleżanek [...] jak to się stało, że zostałeś/ /zostałaś liderem? [...] W jaki sposób zachęcałeś/zachęcałaś innych do zrobienia czegoś? ${ }^{15}$

\footnotetext{
${ }^{13}$ E. Dobrzycka, K. Makara, Wiedza o społeczeństwie 1. Podręcznik dla gimnazjum, Wydawnictwo Pedagogiczne Operon, Gdynia 2010; tychże, Wiedza o społeczeństwie 2. Podręcznik dla gimnazjum, Wydawnictwo Pedagogiczne Operon, Gdynia 2010 - wstęp do każdego z rozdziałów. ${ }^{14}$ A. Pacewicz, T. Merta, O porozumiewaniu się i nieporozumieniach, w: A. Pacewicz, T. Merta (red.), KOSS. Podręcznik i ćwiczenia. Część 1, Civitas, Warszawa 2009, s. 14.

${ }^{15}$ Tychże, Bez wspótpracy ani rusz!, w: tamże, s. 22.
} 
Powyższy przykład znakomicie pokazuje, że stosowanie żeńskich końcówek w obszarach tradycyjnie zarezerwowanych dla mężczyzn jest trudne - proponuje się tu czasowniki wrażliwe na płeć, a jednocześnie używa słowa „lider” w odniesieniu do dziewcząt i chłopców. Skoro stosujemy słowo „zostałaś”, to konsekwentna byłaby forma ,liderką".

Quiz samorządowy

$[\ldots]$

3. Jesteś radnym/radną. Co powinnaś/powinieneś wiedzieć o swoich prawach i obowiązkach? [...]

4. Jesteś burmistrzem/panią burmistrz. Czy jesteś organem stanowiącym, czy wykonawczym $[\ldots]^{16}$

W jednym z ćwiczeń (polegającym na studium przypadków dotyczących etyki w gospodarce) podjęto nawet decyzję o zastosowaniu wyłącznie żeńskich końcówek, co w kontekście dominacji w języku rodzaju męskiego jest ciekawym rozwiązaniem, odwracającym regułę funkcjonującą w języku polskim. Interesujące byłoby sprawdzenie, jak na taki zabieg językowy reagują uczennice i uczniowie.

1. Pracujesz w wytwórni lodów. Zorientowałaś się, że od jakiego czasu do lodów wiśniowych dodawany jest przeterminowany barwnik spożywczy. Gdy powiedziałaś o tym kierownikowi, usłyszałaś [...]

2. Dowiedziałaś się, że firma budowlana, w której pracujesz, bierze udział w przetargu na remont miejskiego ratusza. Właściciel firmy prosi, byś dyskretnie dowiedziała się, jak wygląda oferta waszego głównego konkurenta, korzystając z tego, że sekretarką w tamtym przedsiębiorstwie jest twoja ciotka ${ }^{17}$.

Niestety, jeśli spojrzymy na treść poleceń nie tylko pod kątem językowym, dostrzeżemy schemat dotyczący funkcjonowania mężczyzn na stanowiskach kierowniczych (kierownik, właściciel), a kobiet - jako pracownic/osób wspierających (pracownica wytwórni lodów, firmy budowlanej, sekretarka).

Również proces poszukiwania pracy ma w podręcznikach płeć - uwagę zwraca wzór CV, gdzie Wojciech Pracowity przekazuje informacje o swoim stanie cywilnym oraz braku dzieci, a następnie pisze list motywacyjny do

${ }^{16}$ J. Królikowski, T. Merta, Kto rządzi w gminie?, w: tamże, KOSS, s. 101.

${ }^{17}$ A. Pacewicz, T. Merta, J. Królikowski, O etyce i prawie w gospodarce, w: A. Pacewicz, T. Merta (red.), KOSS. Podręcznik i ćwiczenia. Część 2, Civitas, Warszawa 2010, s. 181. 
Agnieszki Sympatycznej, dyrektorki domu dziecka ${ }^{18}$. Już sam dobór nazwisk niesie ze sobą przekaz dotyczący cech stereotypowo przypisywanych kobietom i mężczyznom, dodatkowo doradza się młodzieży podawanie w dokumentach aplikacyjnych informacji mogących stanowić podstawę dyskryminacji na rynku pracy, częściej dotykającej kobiet (stan cywilny, dzieci, data urodzenia jako informacja o wieku) ${ }^{19}$.

W badanych podręcznikach do historii nie stosowano wymiennie form żeńskich i męskich lub w jakikolwiek inny sposób nie zaznaczano zróżnicowania płciowego występujących postaci. Tekst jest prowadzony z punktu widzenia męskiej narracji, forma żeńska występuje w kilku przypadkach, np. przy użyciu słowa „łączniczki”, odnoszącego się do kobiet służących w podziemiu w trakcie II wojny światowej ${ }^{20}$, a także we fragmencie mówiącym o Organizacji Harcerek i Organizacji Harcerzy (Szare Szeregi) ${ }^{21}$ oraz gdy wspomina się o „młodszych harcerkach i harcerzach"22.

Sporadycznie język równościowy stosowany jest w podręcznikach do języka polskiego oraz wychowania do życia w rodzinie. Są to jednak sprawiające wrażenie przypadkowych próby kierowania poleceń do ćwiczeń zarówno do dziewcząt, jak i chłopców (np. „Porozmawiaj z koleżanką lub kolegą...”). Jednakże próby te nie są konsekwentne - w większości analizowanych pozycji język wrażliwy na płeć miesza się z poleceniami przekazywanymi w sposób tradycyjny (np. „Zapytaj kolegę...”). W efekcie powstaje wrażenie, że część poleceń w podręcznikach i ćwiczeniach jest kierowana wyłącznie do chłopców, gdyż sposób ich sformułowania nie uwzględnia możliwości włączenia dziewcząt $\mathrm{w}$ wykonanie polecenia ${ }^{23}$. Jedna $\mathrm{z}$ badaczek w rekomendacjach pisze wprost, że świadome użycie końcówek w rodzaju męskim i żeńskim oraz przywoływanie postaci obojga płci (np. koleżanki i koledzy) wzmocniłoby wśród

\footnotetext{
${ }^{18}$ E. Dobrzycka, K. Makara, Wiedza o społeczeństwie 2. Podręcznik dla gimnazjum, s. 153-154.

${ }^{19}$ M. Jonczy-Adamska, Analiza podręczników i podstawy programowej - przedmiot wiedza o spoleczeństwie, w: M. Abramowicz (red.), Wielka nieobecna, s. 224.

20 J. Chachaj, Historia - czasy najnowsze. Podręcznik dla III klasy gimnazjum, Wydawnictwo Szkolne PWN, Warszawa 2006, s. 85.

${ }^{21}$ J. Bednarz, M. Litwinienko, K. Zapała, Historia. Podręcznik dla gimnazjum. Klasa 3, Wydawnictwo Pedagogiczne Operon, Gdynia 2007, s. 189.

${ }^{22}$ Tamże, s. 191. M. Dziurok, Analiza podręczników i podstawy programowej-przedmiot historia, w: M. Abramowicz (red.), Wielka nieobecna, s. 184.

${ }^{23}$ M. Pawlęga, Analiza podręczników i podstawy programowej-przedmiot język polski, w: tamże, s. 151 .
} 
nastolatków i nastolatek poczucie, że treści te są adresowane zarówno do chłopów, jak i dziewcząt ${ }^{24}$.

\section{Więcej niż obraz}

Zdjęcia i ilustracje w podręcznikach szkolnych także stanowią ważne elementy ukrytego programu nauczania, i - choć nie poddawano materiału graficznego analizie ilościowej - w badanych podręcznikach można dostrzec pewne tendencje. Jeśli spojrzymy na warstwę ilustracyjną przez pryzmat płci, widzimy bardzo wyraźne różnice. Mężczyźni częściej są przedstawiani jako postacie centralne, osoby pracujące (w rozdziałach poświęconych bezrobociu aktywnie poszukujące pracy), osoby podejmujące decyzje - ze względu na swoją rolę zawodową lub społeczną. $\mathrm{W}$ podręcznikach, przy omawianiu różnych tematów, pojawiają się zdjęcia mężczyzn (konkretnych postaci historycznych lub współczesnych, a także anonimowych) w garniturach lub mundurach (wojsko, policja) oraz zdjęcia kobiet w strojach nieformalnych, sugerujących pozostawanie w sferze prywatnej. Mężczyźni częściej pokazywani jako osoby z zainteresowaniami, aktywnie spędzające wolny czas, a także osoby „biorące sprawy w swoje ręce" - powtarzające się zdjęcia mężczyzn protestujących, przemawiających do dużych grup ludzi.

Kobiety i dziewczęta są ukazywane w kontekście domowym (chociaż bardzo rzadko samodzielnie, częściej z całymi rodzinami), a także jako osoby pomagające innym (opiekunki, wolontariuszki). Zdjęcia kobiet w strojach ludowych często towarzyszą opisom mniejszości narodowych i etnicznych, pokazuje się także muzułmanki w burkach i czadorach. Takie przekazy sprowadzają charakterystykę mniejszości do charakterystycznego, często kobiecego, stroju - koncentrują uwagę odbiorczyń i odbiorców wyłącznie na wyglądzie kobiet.

Osoby ukazywane na zdjęciach to w większości osoby białe - osoby o innym niż biały kolorze skóry są pokazywane głównie w kontekście konfliktów zbrojnych, wojen domowych czy uchodźstwa. Niewiele jest sytuacji, w których pokazywane są osoby różniące się wyglądem od większości osób mieszkających w Polsce, a jednocześnie funkcjonujące w polskim społeczeństwie. Bardzo rzadko pojawiają się osoby z niepełnosprawnościami, co powoduje, że ludzie funkcjonujący z różnymi rodzajami niepełnosprawności są w zasadzie niewidoczni w społeczeństwie, a zatem ich problemy i potrzeby również umykają

${ }^{24}$ M. Chustecka, Analiza podręczników i podstawy programowej - przedmiot wychowanie do życia $w$ rodzinie, w: tamże, s. 282. 
uwadze osób zdrowych. W podręcznikach bardzo wyraźnie jest promowany jeden model rodziny - pełnej, tworzonej przez parę heteroseksualną, najczęściej bardzo szczęśliwej. Nie ma przestrzeni dla samodzielnych (samotnych) rodziców ani dla rodziców homoseksualnych. Nie widzimy także rodzin zastępczych czy „patchworkowych” (inaczej rodzin „wieloczęściowych”, „poskładanych”rodzin, w których wspólnie z dorosłymi tworzącymi związek żyją na przykład dzieci z pierwszych związków obojga rodziców i dzieci wspólne).

Pojedyncze zdjęcia przełamują pewne schematy i stanowią dobre praktyki, które warto tu podkreślić: $\mathrm{w}$ jednym z podręczników można znaleźć zdjęcie chłopca wałkującego ciasto, kilku mężczyzn zajmujących się dziećmi, zdjęcia sufrażystek domagających się praw wyborczych dla kobiet czy kobiet prowadzących własną firmę. Tego typu rozwiązań jest jednak w analizowanych podręcznikach znacznie mniej niż takich, które stereotypy wzmacniają.

\section{Podsumowanie}

Reasumując, podręczniki, w których można dostrzec wyraźne wysiłki na rzecz znoszenia dominacji rodzaju męskiego czy męskoosobowego w języku, wciąż należą do mniejszości. Warto te próby docenić, jednocześnie zachęcając do konsekwentnego stosowania równościowego języka we wszystkich przekazywanych treściach. W kontekście nazw stanowisk/zawodów, jak w powyższym przykładzie, wciąż mamy do czynienia z uproszczeniami, do których jesteśmy (również językowo) przyzwyczajeni i przyzwyczajone - pojawiają się dziennikarze, politycy, dyrektorzy, towarzyszą im ekspedientki, woźne, sekretarki, pielęgniarki. Takie schematy trzeba przełamywać, pamiętając, że język także buduje świadomość dotyczącą różnych zjawisk społecznych.

Bardzo podobne rekomendacje dotyczą warstwy ilustracyjnej podręczników - ujmowanie graficzne wyłącznie grup większościowych, podtrzymywanie stereotypowego podziału ról stanowi złą praktykę i należy to zmienić. Obrazy powinny odzwierciedlać różnorodność panującą w społeczeństwie, promować wspólne funkcjonowanie przedstawicielek oraz przedstawicieli mniejszości i większości.

Hasła „szacunek” i „tolerancja” powinny wreszcie wyjść ze szkolnych programów wychowawczych, zejść z gazetek i znaleźć swoje odzwierciedlenie w rzeczywistości każdej szkoły. 


\section{Bibliografia}

Bednarz J., Litwinienko M., Zapała K., Historia. Podręcznik dla gimnazjum. Klasa 3, Wydawnictwo Pedagogiczne Operon, Gdynia 2007.

Chachaj J., Historia - czasy najnowsze. Podręcznik dla III klasy gimnazjum, Wydawnictwo Szkolne PWN, Warszawa 2006.

Chustecka M., Analiza podręczników i podstawy programowej-przedmiot wychowanie do życia $w$ rodzinie, w: M. Abramowicz (red.), Wielka nieobecna - o edukacji antydyskryminacyjnej w systemie edukacji formalnej w Polsce. Raport z badań, Towarzystwo Edukacji Antydyskryminacyjnej, Warszawa 2011.

Cieślikowska D., Postrzeganie społeczne, w: M. Branka, D. Cieślikowska (red.), Edukacja antydyskryminacyjna. Podręcznik trenerski, Willa Decjusza, Kraków 2010.

Dobrzycka E., Makara K., Wiedza o społeczeństwie 1. Podręcznik dla gimnazjum, Wydawnictwo Pedagogiczne Operon, Gdynia 2010.

Dobrzycka E., Makara K., Wiedza o społeczeństwie 2. Podręcznik dla gimnazjum, Wydawnictwo Pedagogiczne Operon, Gdynia 2010.

Dziurok M., Analiza podręczników i podstawy programowej - przedmiot historia, w: M. Abramowicz (red.), Wielka nieobecna - o edukacji antydyskryminacyjnej w systemie edukacji formalnej w Polsce. Raport z badań, Towarzystwo Edukacji Antydyskryminacyjnej, Warszawa 2011.

Jonczy-Adamska M., Analiza podręczników i podstawy programowej - przedmiot wiedza o społeczeństwie, w: M. Abramowicz (red.), Wielka nieobecna - o edukacji antydyskryminacyjnej w systemie edukacji formalnej $w$ Polsce. Raport $z$ badań, Towarzystwo Edukacji Antydyskryminacyjnej, Warszawa 2011.

Królikowski J., Merta T., Kto rządzi w gminie?, w: A. Pacewicz, T. Merta (red.), KOSS. Podręcznik i ćwiczenia. Część 1, Civitas, Warszawa 2009.

Meighan R., Socjologia edukacji, Wydawnictwo Uniwersytetu Mikołaja Kopernika, 1993 Toruń.

Pacewicz A., Merta T., O porozumiewaniu się i nieporozumieniach, w: A. Pacewicz, T. Merta (red.), KOSS. Podręcznik i ćwiczenia. Część 1, Civitas, Warszawa 2009.

Pacewicz A., Merta T., Bez wspótpracy ani rusz!, w: A. Pacewicz, T. Merta (red.), KOSS. Podręcznik i ćwiczenia. Część 1, Civitas, Warszawa 2009.

Pacewicz A., Merta T., Królikowski J., O etyce i prawie $w$ gospodarce, w: A. Pacewicz, T. Merta (red.), KOSS. Podręcznik i ćwiczenia. Część 2, Civitas, Warszawa 2010.

Pawlęga M., Analiza podręczników i podstawy programowej - przedmiot język polski, w: M. Abramowicz (red.), Wielka nieobecna - o edukacji antydyskryminacyjnej $w$ systemie edukacji formalnej w Polsce. Raport z badań, Towarzystwo Edukacji Antydyskryminacyjnej, Warszawa 2011. 
Podstawa programowa kształcenia ogólnego dla szkót podstawowych, s. 2, http://www. bip.men.gov.pl/men_bip/akty_prawne/rozporzadzenie_20081223_zal_2.pdf (dostęp: 9.10.2013).

\section{Antidiscrimination education and the hidden curriculum. Word and picture}

\section{Summary}

The article establishes the analysis of the findings outcomes executed by The Antidiscrimination Education Association (TEA) in frames of the project Significant Absenceon anti-discrimination education in the formal education system in Poland in terms of the occurrence of a hidden curriculum in context of passing contents regarding groups which are discriminated and excluded. The analysis was submitted to verbal and graphic content in polish handbooks, as well in what way the language carries biases and shapes the perception of different social groups.

Keywords: antidiscrimination education, education, hidden curriculum. 